\title{
Resale Price Maintenance: What Future, What Past?
}

\author{
Varun Chakravarty \\ Undergraduate Student B.A.LL. B (hons.), National Law University Raipur, India, varunchakravarty.hnlu@gmail.com
}

\begin{abstract}
The paper deals with a comprehensive analysis of the evolution of vertical price restraints in the American, European and Indian market. Resale price maintenance refers to the efforts of a manufacturer to restrict the range of prices charged by a retailer of the manufacturer's product. In this paper there will be an analysis of evolution of resale price maintenance in US with the inception of Sherman Act to Leegin Creative Leather case for maximum and minimum resale price maintenance. There will also be an analysis of evolution of US competition law from Per-se to Rule of reason with regard to incident of checking the anti-competitive market practice. A detailed analysis with respect to US, EU and Indian stand on competition law will be given in this research paper.
\end{abstract}

KEYWORDS: Resale price maintenance, Competition law, Rule of Reason

\section{Introduction}

A resale price maintenance (RPM) agreement is a contract in which a manufacturer and a downstream distributor (retailer) agree to a minimum or maximum price the retailer will charge its customers (consumers) (Mills and Elzinga 2008, 1841-1858). Resale price maintenance can be used to retain control over the services offered in the market but in certain cases the agreements between parties are per se showing resale price maintenance. Examples of the latter are an agreement fixing the distribution margin, fixing the maximum level of discount the distributor can grant from a prescribed price level, making the grant of rebates or reimbursement of promotional costs by the supplier subject to the observance of a given price level, linking the prescribed resale price to the resale prices of competitors, threats, intimidation, warnings, penalties, delay or suspension of deliveries or contract terminations in relation to observance of a given price level. Immediate or aberrant methods for accomplishing value fixing can be made progressively viable when joined with measures to distinguish value cutting wholesalers, for example, the usage of a value checking framework, or the commitment on retailers to report different individuals from the dispersion arrange who go amiss from the standard value level. Additionally, immediate or roundabout value fixing can be made increasingly powerful when joined with measures which may lessen the purchaser's impetus to bring down the resale cost, for example, the provider printing a prescribed resale cost on the item or the provider obliging the purchaser to apply a most-favored client statement and so on.

It has been argued that through price maintenance, a supplier can exercise some control over the product market. This form of vertical price fixing may prevent the margin from retail and wholesale prices from being reduced by competition. However, an alternative argument is that the supplier may wish to protect the reputation or image of the product and prevent it from being used by retailers as a loss leader to attract customers. Also, by maintaining profit margins through RPM, the retailer may be provided with incentives to spend greater outlays on service, invest in inventories, advertise and engage in other efforts to expand product demand to the mutual benefit of both the supplier and the retailer. RPM may also be used to prevent free riding by retailers on the efforts of other competing retailers, who instead of offering lower prices expend time, money and effort promoting and explaining the technical complexities or attributes of the product. (OECD Glossary, n.d.) For example, one retailer may not reduce price but explain and demonstrate to customers the use of a complex product such as a computer. The customer may after acquiring this information choose to buy the computer from a retailer that sells it at a lower price and does not explain or demonstrate its uses (Problem of free-riding). In many countries, RPM is per se illegal with few exceptions or exempt products. Many economists now advocate adopting a less stringent approach in competition law towards RPM and other vertical restraints. Resale price maintenance 
has the ability to restrict competition in a primarily vertical fashion. They involve arrangements on a vertical chain, such as bilateral agreements between a manufacturer and a retailer. In contrast with horizontal collusion, vertical agreements are common and essential in a market consisting of bilateral or multilateral agreements. All these arrangements can include restrictive aspects which can lessen competition, primarily, intra-band competition. In this paper we will talk about how the policy differ in EU and US law regime.

\section{Evolution of RPM in United States}

The United States was one of the first countries to introduce the modern antitrust (Competition law). An important piece of US legislation the Sherman Act (Sherman Act 1890) was enacted in 1890. It created the most important basis for the law of vertical restraints. However, it would be wrong to suppose that antitrust law and policy, including the law of vertical restraints, has not changed since 1890 .US antitrust policy has been constantly evolving, in some areas, such as vertical restraints, more than others.

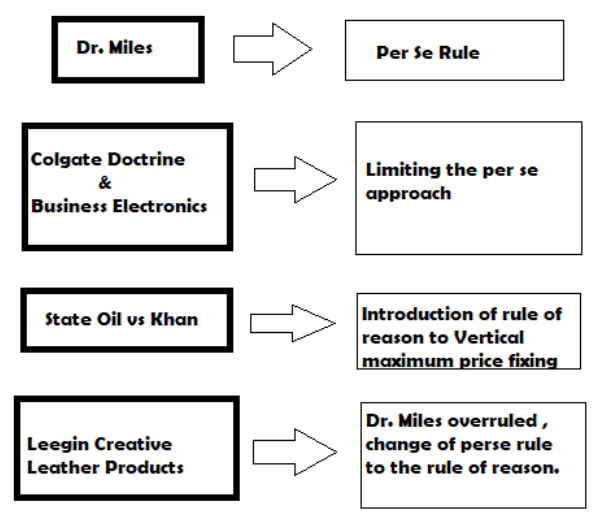

Figure 1. Evolution from per se to rule of reason

The First important milestone for the approach to RPM was the case of Dr. Miles(220 U.S. 373(1911)), which introduced the per se rule in 1911. Since then many changes have been adopted, with the Colgate(250 U.S. 300(1919) doctrine from 1919 and Business Electronics(485 U.S.717(1988)) arguably limiting the per se approach in 1988, The Miller- Tydings Act in 1937 and McGuire Act in 1952 allowed RPM under state statutes, both of which were repealed by the Consumer Goods pricing Act in 1975. Khan (522 U.S. 2(1997)) introduced the rule of reason to vertical maximum price fixing in 1997 and ten years later, the Supreme Court overruled Dr. Miles in Leegin,( 551 U.S. 877 (2007)) which changed the per se rule to rule of reason.

\section{RPM: Leegin: Rule of Reason}

In the case of Leegin Creative Leather Product Ltd, the Supreme Court introduced the rule of reason to agreements on vertical price fixing and minimum price fixing, overruling the Dr. Miles Doctrine, which set the per se rule for vertical minimum price collusion. Leegin involved RPM in the form of minimum price seeing.

Leegin Creative Leather Products, a maker of ladies' extras, went into vertical least value concurrences with its retailers. The understandings required the retailers to charge within certain base costs for Leegin items. As per Leegin, the value essentials were expected to energize rivalry among retailers in client administration and item advancement. When one retailer, PSKS, limited Leegin items beneath the base value, Leegin dropped the retailer. PSKS sued, contending that Leegin was damaging Section 1 of the Sherman Act by taking part in anticompetitive value fixing. Under the Supreme Court's 1911 choice in Dr. Miles Medical Co. v. John D. Park and Sons Co., compulsory least value understandings are in essence illicit under the Act - that is, they are naturally unlawful paying little heed to the conditions. 
Leegin contended that this standard depended on obsolete financial aspects. It fought that a superior legitimate investigation would be the "principle of reason," under which value essentials would be held unlawful just in situations where they could be appeared to be anti competitive. Both the District Court and U.S. Court of Appeals for the Fifth Circuit dismissed these contentions. The courts felt constrained to pursue the Supreme Court's standard in the Dr. Miles case, under which Leegin's practices were illicit paying little heed to the monetary contentions set forward by the organization.

The Supreme Court majority conclusion held that Dr. Miles had blundered by treating vertical least value understandings among producers and retailers as comparable to even value fixing understandings between venders. The Court referred to confirm from the financial writing that vertical least cost understandings are once in a while anti competitive and can regularly capacity to increment between brand rivalry. The Court recognized that now and again vertical value essentials may encourage producer cartels, yet it held that cases where the value understandings are manhandled for illicit anti competitive purposes can be resolved on a case-by-case premise under the standard of reason. The unimportant actuality that vertical value essentials may prompt more expensive rates for merchandise can't think about adversely its lawfulness under the Sherman Act, in light of the fact that there are many genuine business choices that may at last outcome in more expensive rates. The lion's share likewise recognized that the rule of stare decisis would weigh against overruling the almost 100-year-old point of reference in Dr. Miles, however it held that the Sherman Act is to be treated as a "custom-based law resolution," which must be permitted to advance in the courts as financial learning and conditions change. The nonconformists, in a feeling created by Justice Stephen Breyer, saw no adjustment in conditions that would legitimize overruling Dr. Miles, and they contended that the dependence of the business network on that choice bolstered adherence to stare decisis.

\section{Pro-competitive and Anti-Competitive Effects of RPM on Competition}

The Supreme Court recognized three principle procompetitive justifications for overruling the per se rule in Leegin's case:

1. The free riding theory

2. New entrant justification; and

3. Increasing inter-brand competition by providing services.

This leads us to the following pro-competitive and anti-competitive effects:

\section{Beneficial effects}

Vertical restraints can be employed to reduce transaction costs or to achieve other efficiencies between firms at different levels of the production and distribution chain (Rey and Verge 2004). Vertical restraints, like exclusive distribution can also help to solve the potential problem of under investment. It has to be observed that when the pro-competitive effects of an agreement outweigh its anti-competitive effects the agreement is on balance. The primary goal of these agreements is to promote the spirit of competition in the market by promoting better services and prices of the products in market by increasing competition between rivals so ultimately its the consumers who are benefitted.Another benefit which derives from resale price maintenance relates to "double marginalization". The intuition behind double marginalization is that if both the producers and distributors add markups over their costs. The resulting "double" markups will lead to excessive prices. In this resale price maintenance could help the manufacturer by bringing the prices down to joint profit maximizing level (Peeperkorn 1998).

Resale price maintenance also provides a solution for the free rider problem.It has to be understood that those established distributors who have already invested on products will nit be interested in promoting services for new products as the new entrants will just free ride on the services provided by the established distributors. Hence it is essential that a certain degree of cap is 
to be imposed even for the new entrants to invest on the point of sale services and maintaining balance among the distributors. This is particularly true with respect to products that require certain pre-purchase services due to its technical complexity.

Furthermore, resale price maintenance can also increase sales and create brand image by imposing certain standards of quality on the distributors in result of which there will be an increase in competition among inter-brands by providing services.

\section{Anti-competitive Effects}

Vertical restraints can also lead to anti-competitive effects. Negative anti-competitive effects, which may result from vertical restraints, are: foreclosure by raising barriers to entry, reduction of interbrand competition (including facilitation of collusion, both explicit and tacit), reduction of intrabrand competition, and creation of obstacles to market integration (Hughes, Foss and Ross 2001, 427).

If a single vertical agreement provides a major chunk of market power resides with few suppliers and manufacturers then it will result in negatively impacting the economy. The efficiency in prices can only be observed by the consumers if there is a likelihood of competition between suppliers of goods and services exists. Other wise if they entail the majority share in the market those efficiency will be negated as extra profits.

It has to be observed that a series of exclusive distribution agreements between a producer and a large number of distributors can shield a market from new entrants ((1991) ECR 935.). In such cases the positive effect on competition of vertical agreements is easily offset by their detrimental effect of hindering the emergence of new competitors.

Another competition risk is that certain buyers within that market can no longer buy from this particular supplier, i.e. it leads to foreclosure of certain buyers. In the case of wide exclusive territories or customer allocation, the result may be total elimination of intra-brand competition.

\section{Vertical Agreement \& RPM in European Union}

Vertical agreements are agreements made between undertakings operating at different levels of the same market. The European Union's treatment, particularly by the Commission, of vertical agreements has historically been criticized for failing to create an effective framework. The commission aware of the criticisms of its approach initiated a process of reform which culminated in the adoption of the first Vertical Agreements Regulation (European Union Law 1999) which was replaced by the current Vertical Agreements Block Exemption Regulation (the "VABER") in 2010.

VABER and its accompanying guidelines provide a safe harbor to those vertical agreements which fulfills certain conditions.

The 'umbrella' exemption approach adopted ensures that every type of restraint is permitted unless it is strictly prohibited. Using only a black list of prohibited terms increase the flexibility of parties allowing them to adopt agreements that are appropriate for their commercial setting.

\section{Market Share Threshold}

Following the Commission Communication's focus on market power, Art 3 of the regulation creates a safe haven for all vertical agreements, subject to Art 4, where:

The market share held by the supplier does not exceed $30 \%$ of the relevant market on which it sells the contract goods or services and the market share held by the buyer does not exceed $30 \%$ of the relevant market on which it purchases the contract goods or services.

\section{Hardcore Restrictions}

The 'black list' of hardcore restrictions is provided in Art 4 of the Regulation. Article 4 sets out the list of provisions which are prohibited and which will render an agreement not capable of exemption under the regulation. 


\section{Resale Price Maintenance}

Article 4(a) provides that resale price maintenance is considered to be a hard-core restriction, whether it is imposed directly by fixing a minimum resale price or indirectly, by fixing discount levels or linking threats of delayed supplies or penalties to the observance of a recommended price level. There is no restriction on maximum pricing. This hard-core restriction was until recently largely unobjectionable, but following the US move away from RPM being considered illegal per se in Leegin(551 U.S. 887 (2007) (Sup Ct (US))) the debate about the anti- competitive effect of vertical price fixing in EU has reopened(Zevogolis 2013).

The new Guidelines, however, recognize three situations in which RPM could cause efficiencies to the benefit of consumers and so may be exempted under Art. 101(3): 'Firstly, resale price maintenance may be necessary to induce distributors to promote a new product when it is not practical to achieve this result contractually. Secondly, resale price maintenance may be necessary to organize short-term (six to eight weeks) promotions in distribution agreements belonging to a franchise system or similar distribution system applying a uniform distribution system (arguably, selective distribution systems). Thirdly, the parties may demonstrate that resale price maintenance is a means to avoid free riding of pre-sale services, in particular, in the case of experienced resellers or complex products (Stefano 2010,487).

\section{The Future of hardcore restrictions or restrictions by object}

Jones et al. have found that the Commission and the ECJ have a different understanding of restrictions by object(Jones 2010 649-656) The Commission states that restrictions by object are those which 'by their very nature' are likely to produce negative effects on the market and to jeopardize the objectives pursued by EU competition rules. Because of their high potentiality to produce negative effects, there is no need to assess their 'actual effects on the market'. However, the ECJ finds that to determine whether conduct is 'by its very nature' injurious to competition or anti-competitive by nature (restrictive by object), 'regard must be given inter alia to the content of its provisions, the objectives it seeks to attain and the economic and legal context of which it forms a part'((2009) ECR I-9291)

\section{Per se and Rule of Reason With respect to RPM}

\section{In United States}

In the US there is a dual approach to the consideration, under section 1 of the Sherman Act, of restrictions in vertical agreements (Rodger and Macculloch 2015). Some restraints of trade are considered to be illegal per se and others are subject to the 'rule of reason' in order to determine whether they are reasonable or unreasonable. The major development in US antitrust law has been the dramatic reduction in restrictions which are subject to the per se test, which is now limited, for instance, to horizontal market division and price-fixing; the per se test no longer applies to vertical resale price maintenance. Under the per- se rule, no further inquiry is made into the existence of anti-competitive effects, market power or intent.

The rule of reason test, which requires consideration of the impact of the restraint on competitive conditions, is more complex. It now applies to all of vertical restraints and requires a detailed economic analysis of the restraint, market structure and market conditions to assess the restraint likely pro- and anti- competitive effects. The first major step in the direction was the US Supreme court decision in Continental TV Inc vs GTE Sylvania(433 US 36 (1977)), which confirmed that the rule of reason test should be applied to non-price vertical restraints to access their legality. After Sylvania, US authorities have adopted a particularly tolerant approach to most vertical restraints based primarily on free-rider rationale(Calavni 2001, 201) The Sylvania rule of reason test was extended to vertical resale price maintenance by the majority of the Supreme Court in 2007 in Leegin Creative Leather Products Inc v PSKS Inc (127 SCt 2705 US (2007)) 


\section{In European Union}

The Commission, perhaps influenced by the Leegin judgement, has indicated a willingness to adopt a more lenient approach to fixed and minimum RPM. Although it has retained their exclusion from the current block exemption on vertical restraints in the revised accompanying guidelines the commission is willing to apply a more rigorous assessment of the alleged negative effects when an efficiency defense is raised.

Though it still considers a particular type of trade restraint to be so anti-competitive that no inquiry is required and the adjudicating authority presumes that the party has indulged in anticompetitive practice on fulfillment of certain conditions. It has to be noted that both rule of reason and per se are not rules of fact; rather they determine the burden of proof.

Accordingly, the commission has distinguished between types of vertical restraints which have the object of restricting competition, which could be described as per se prohibition such as export bans, and other vertical restraints which requires an economic analysis of the effects of an agreement.

\section{Policy conclusions on vertical restraints}

Resale price maintenance can result in both anti and positive competitive features. Resale price maintenance can only be of concern when the competition among brands is not sufficient, which means that there is an unusual share of market power being held by either the retailer or supplier. Incidentally If market is filled with many firms competing with each other which will result in an decentralized market and an absence in anti competitive effects in the market. So it has to be observed that those contracts which provides exclusivity to both manufacturers and retailers will always pertain to anti competitive effects in the market and hence should be filtered out when scaling resale price maintenance or vertical agreements in general.

\section{Resale price maintenance in India with respect to orders of Competition Commission of India}

Explanation (e) to s. 3(4) of the Competition Act describes that resale price maintenance includes any agreement to sell goods on condition that the prices to be charged on the resale by the purchaser shall be the prices stipulated by the seller unless it is clearly stated that prices lower than those prices may be charged.

Any RPM agreement constituting under section 3(4) e has to go through the test laid down by Section 19(3).

Section 19(3) of the Act states that while determining whether an agreement has an appreciable adverse effect on competition under section 3, the Commission shall give due regard to all or any of the following factors:

a) creation of barriers of new entrants in the market;

b) driving existing competitors out of the market;

c) foreclosure of competition by hindering entry into the market;

d) accrual of benefits to consumers;

e) improvements in production or distribution of goods or provision of services;

f) Promotion of technical, scientific and economic development by means of production or distribution of goods or provision of services.

\section{CCI's adjudication on RPM}

In the case of M/s Fx Enterprise Solutions India Pvt. Ltd. V. M/s Hyundai Motor India Limited (CCI 2018) 
For the first time the Competition Commission of India upon DG investigation it was observed that Hyundai has imposed a restriction on the amount of discount which can given by the dealers. Hence it was observed that the company had a discount control mechanism through creating a ceiling of maximum permissible discounts, which created an appreciable adverse effect on competition which resulted in a penalty of INR 87 crores being imposed.

\section{Findings \& Conclusion}

The economic approach to RPM is outcome oriented; however, final outcomes are uncertain. It cannot be said that RPM is always pro competitive or anticompetitive. Whether a particular RPM practice is anticompetitive or procompetitive differs from case to case. Moreover, it also depends on the method and theory used for the outcome measurement. RPM do not necessarily lead to increased inter-brand competition as advocated by US approach to RPM but, on the contrary they can decrease inter-brand competition. Whether fixed and minimum RPM may truly provide significant efficiencies so as to offset its negative effects remain controversial. While most economists theorize about the benefits of RPM, some commentators such as Peeperkorn seriously question the robustness of arguments supporting the view in favor of efficiencies by RPM. There is much to be said for maintaining a presumption of illegality in respect of fixed and minimum RPM; but one that allows for its rebuttal by the undertakings concerned where they can provide solid evidence of verifiable efficiency claims that may be passed on to consumers, as is the case under EU law.

EU competition law, including the law on vertical restraints is based on two principal objectives:

1. A competition law objective: the protection of competition, in particular, protecting free and fair competition and enhancing consumer welfare; and

2. The EU- purpose objective: establishing and maintaining an integrated market.

In India the concept of Resale price maintenance, Section 3(4) (e) is observed through a 'rule of reason framework 'of its pro-competitive and anti-competitive effect. This has been laid down with respect to the provisions given in Section 19(3) of the Competition law, in which the factors under section 19(3) a to c (anti-competitive effects) is weighed against the pro-competitive factors, $\mathrm{d}$ to $\mathrm{f}$. If RPM is disrupting the market and is presumed to cause an appreciable adverse effect on competition (AAEC), then appropriate action will be taken by the Commission.

\section{References}

Calavni, T. 2001. "Some Thoughts on the Rule of Reason." 6 European Competition Law Review: 201.

Case 234/89, Delimitis S. v. Henninger Brau,28.2.1991, (1991) ECR 935.

CCI (Competition Commission of India). 2018. "Case Nos. 21, 29, 36, 47, 48 \& 49 of 2013” Accessed on December 3, 2018.https://www.cci.gov.in/sites/default/files/C.\%20Nos.\%2021\%2C29\%2C36\%2C47\%2C48\%20\%26\%2049 $\% 20$ of $\% 202013$.pdf.

Continental TV Inc vs GTE Sylvania 433 US 36 (1977).

Dr. Miles Medical Co v. John d Park \& Sons Co., 220 U.S. 373(1911).

Duns, John., Duke, Arlen., Sweeney and Brenden. 2015. Comparative Competition Law. Edward Elgar Publishing Limited.

European Union Law. 1999. "Regulation 2790/99/EC of Art 81(3), [1999] OJ L336/21.” Accessed December 5, 2018. https://eur-lex.europa.eu/LexUriServ/LexUriServ.do?uri=OJ:L:1999:336:0021:0025:EN:PDF.

Gianni De Stefano. 2010 "The new EU "Vertical Restraints Regulation": navigating the vast sea beyond safe harbors and hardcore restrictions." European Competition Law Review: 487- 489.

Hildebrand, Doris. 2005. Economic Analysis of Vertical Agreements - A Self-Assessment, Kluwer Law International.

Hylton, Keith N. 2003. Antitrust Law Economic theory \& Common law evolution, $1^{\text {st }}$ edition, University Press Cambridge.

Jedlickova, Barbora. 2016. Resale Price Maintenance \& Vertical Territorial Restrictions Theory and Practice in EU Competition Law and US Antitrust Law. Northampton, MA: Edward Elgar Publishing Limited.

Joined Cases C-501, 513, 515 \& 519/06, GlaxoSmithKline Services Unlimited v Commission [2009] ECR I-9291, para 58. 
Jones, Alison. 2010. "Left behind by modernization? Restrictions by object under Article 101 (1)" European Competition Journal: 649-656. See also Craig Callery. 2011. 'Should the European Union embrace or exorcise Leegin's “rule of reason"?' European Competition Law Review 42 -45.

Leegin Creative Leather Products Inc v PSKS Inc, 551 U.S. 887 (2007) (Sup Ct (US)).

Hughes, M., Foss, C., and Ross, K. 2001. "The economic assessment of vertical restraints Under U.K. and E.C. Competition Law." European Competition Law Review: 427.

Mills, David E \& Elzinga, Kenneth G. 2008. "The Economics of Resale Price Maintenance.” In 3 Issues in Competition Law and Policy, 1841-1858. ABA Section of Antitrust Law.

OECD: Glossary. n.d. "Resale Price Maintenance" Accessed December 3, 2018. Available at https://stats.oecd.org/glossary/detail.asp?ID=3298

Peeperkorn. L. 1998.” The Economics of verticals.” Competition Policy Newsletter.

Rey, P. and T. Verge. 2005. "The economics of vertical restraints", paper Presented at "Advances of the Economics of Competition Law" Rome June 2005. Learlab http://www.learlab.com/conference2005/documents/rey_verge.pdf

Rodger, Barry J., MacCulloch, Angus. 2015. Competition Law and Policy in the EU and UK, $5^{\text {th }}$ edition, Routledge.

Sherman Antitrust Act 15 USC 1-7, 26 Stat 209 (1890).

United States v. Colgate \&C0., 250 U.S. 300(1919).

Zevogolis, NE. 2013. "Resale Price Maintenance (RPM) in European Competition Law: Legal Certainty Versus Economic Theory" European Competition Law Review: 25. 